\title{
Сибирские влияния в растительном покрове Джунгарского Алатау
}

\section{Siberian influences in vegetative cover of Dzungarian Alatau}

\author{
Данилов М. П., Ситпаева Г. Т., Кудабаева Г. М., Веселова П. В., Шорманова А. А., Курмантаева А. А. \\ Danilov M. P., Sitpayeva G. T., Kudabayeva G. M., Vesselova P. V., Shormanova A. A., Kurmantayeva A. A. \\ Институт ботаники и фитоинтродукиии КН МОН РК, г. Алматы, Казахстан. \\ E-mail:michaelpetrovich@mail.ru; sitpaeva@mail.ru
}

Institute of botany and phytointroduction of the Committee of Science of the Ministry of Education

and Science of the RK, Almaty, Kazakhstan

\begin{abstract}
Peфepam. Рассматриваются бореальные элементы растительного покрова Джунгарского Алатау общие с Алтаем и другими горными системами Сибири. Описан джунгарский вариант черневой тайги на примере сочетания высокотравных полян и пихтово-осиновых лесов.
\end{abstract}

Ключевые слова. Бореальные элементы, ботанико-географическое районирование, Джунгарский Алатау, растительность, растительный покров, флора.

Summary. The northern boreal element in vegetative cover of Dzungartan Alatau Mountains, which common with Altai and other mountains of Siberia were considered. The dzungarian variant of chernavaja taiga was described on example of combination of fir-aspen forests and highly herb glades.

Key words. Boreal elements, botanical-geographic regionalization, Dzungartan Alatau, flora, vegetation, vegetative cover.

Горная система Джунгарского Алатау расположена в юго-восточной части Казахстана и относится к Семиречью или Джетысу, занимая пространство вдоль границы Казахстана с Китаем между горами Тарбагатай и р. Или. По хребту Боро-Хоро она соединяется с Тянь-Шанем.

Регион издавна привлекал внимание ботаников. Большие гербарные сборы проводили А. Г. Шренк в 1840, 1841, 1843 гг. (АА), Г. С. Карелин и И. П. Кирилов в 1840 и 1841 гг. (АА), Н. В. Павлов и С. Ю. Липшиц в 1928 г. (АА), В. П. Голоскоков в 1936-1971 гг. (АА) и многие другие исследователи. В результате во флоре Джунгарского Алатау выявлено 2168 видов сосудистых растений (Голоскоков, 1984).

По новейшей системе ботанико-географического районирования горы Джунгарского Алатау относятся к Джунгаро-Северотяньшаньской горной провинции Сахаро-Гобийской пустынной области. Отличительной чертой этой провинции от других частей Средней Азии является значительное присутствие в растительном покрове бореальных элементов, характерных для Алтая и других гор Южной Сибири (Волкова, 2003). Ярким примером этому может служить присутствие в моховых еловых лесах Тянь-Шаня и Джунгарского Алатау широко распространенных бореальных горно-таежных растений Goodyera repens (L.) R. Br., Hypopytis monotropa Crantz, Pyrola rotundifolia L., P. minor L., Moneses uniflora (L.) A. Gray, Orthilia obtusata (Turcz.) Hara, Adoxa moschatellina L., а как тундровый элемент -Arctous alpina (L.) Niedenzu в высокогорьях.

Среди горных систем Средней Азии и Казахстана Джунгарский Алатау выделяется в качестве значительного рубежа между ботанико-географическими элементами Сибири и Средней Азии. «Черты растительности Алтая и Сибири ... ощутимы в большей степени, чем в других частях... Некоторые представители бореальной флоры, попадая в эти горы, не выходят за их пределы» (Коровин, 1962: 387). Здесь находятся крайние южные местонахождения таких значимых видов- как Abies sibirica Ledeb., 
Lilium martagon L., Betula pendula Roth, Clematis integrifolia L., Berberis sibirica Pall., Rhodiola rosea L., Grossularia acicularis (Smith) Spach,, Spiraea chamaedrifolia L., S. trilobata L., Pentaphylloides fruticosa (L.) O. Schwarz, Biebersteinia odora Steph., Peucedanum morisonii Bess.ex Spreng, Galium odoratum (L.) Scop., Antennaria dioica (L.) Gaertn, Alfredia cernua (L.) Cass., Rhaponticum carthamoides (Willd.) Iljin и многие другие представители бореальной флоры и гор Южной Сибири из различных вертикальных поясов.

Особенно отчетливо связь растительного покрова Джунгарского Алатау с горными системами Сибири проявляется на его северном макросклоне. Мы провели исследования в Лепсинском подрайоне Северо-Джунгарского геоботанического района (Рубцов, 1948) (Североджунгарской горной подпровинции по Е. А. Волковой (2003)) в 2018 г. В этом подрайоне находятся самые большие площади горных лесов в Средней Азии (Рубцов, 1948; Волкова, 2003 и др.) с участием Picea schrenkiana Fisch. et C. A. Mey., Abies sibirica Ledeb., Populus tremula L., Malus sieversii (Ledeb.) M. Roem., Betula pendula Roth.

В окрест. с. Лепсинск в лесолуговом поясе находится обширный лесной массив, расположенный между реками Большой Баскан и Лепсы. Здесь отмечены наибольшие площади яблоневых лесов (Волкова, 2003). Наше внимание привлекла нижняя полоса массива южнее с. Тополёвки вдоль левого берега р. Теректы в районе кордонов Кокжоты и Осинники Жонгар-Алатауского государственного национального природного парка (ГНПП). Примечательно, что в составе лесов в нижней полосе массива из осины, пихты, яблони и березы полностью отсутствует ель Шренка (Picea schrenkiana). Обычно в Джунгарском Алатау пихта встречается в качестве небольшой примеси в ельниках. Здесь же представлены пихтовые леса в сочетании с осинниками и яблоневыми насаждениями. Впервые почти чистые пихтовые леса в Джунгарском Алатау были обнаружены Л. И. Родиным в 1933 г. в среднем течении р. Лепсы (Рубцов, 1948), но их описания не были приведены.

В целом, лугово-лесная растительность в районе кордонов Кокжоты и Осинники сходна с черневой тайгой нижней части лесного пояса в Западном Алтае и других гумидных районах Южной Сибири. Главное отличие от сибирской растительности заключается в присутствии в пихтовых и осиновых древостоях междуречья Улькен-Баскан и Лепсы яблони Сиверса (Malus sieversii).

Ландшафт черневой тайги представляет собой сочетание пихтовых лесов при участии осины и высокотравных луговых полян. В окрестностях кордона Кокжоты у подножья одноименной горной вершины (2983 м над ур. м.) в растительном покрове преобладают осиновые леса с пихтой в комбинации с высокотравной луговой растительностью. Возможно, осиновые древостои имеют вторичный характер, т. к. в прошлом хвойные породы деревьев интенсивно вырубались (Рубцов, 1948). Пихтовые леса приурочены к северным склонам и берегам ручьев. Для получения общего представления о структуре растительного покрова рассматриваемого урочища приведем два описания лесной и луговой растительности:

Пихтово-осиновый лес коротконожково-разнотравный с яблоней (N 45²4’45”; Е 080²7’47”; 1542-1565 м над ур. м.) (табл. 1). Высота деревьев - 15-25 м. Сомкнутость крон - 0,6. Ярус кустарников и низких деревьев фрагментарный. Он состоит из пологов крупных кустарников и низких деревьев с яблоней и боярышником (Crataegus korolkovii L. Henry), рябины (Sorbus tianschanica Rupr.) и мелких кустарников подлеска из шиповника (Rosa alberti), смородины Мейера (Ribes meyeri Maxim.), малины (Rubus idaeus L.) и кизильника многоцветкового (Cotoneaster multiflorus Bunge). ОПП травостоя составляет $70 \%$. Под кронами пихты растения отсутствуют.

Высокотравный лисохвостово-борово-разнотравный луг по террасе ручья (N 4525'00,5”;

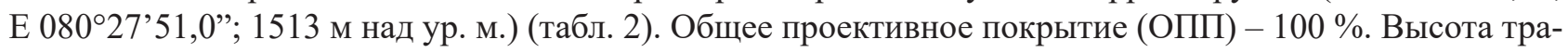
востоя к моменту описания (14 июня 2018 г.), достигала 100 см и более. К концу лета трава, возможно, превысит человеческий рост. Среди травостоя встречаются экземпляры яблони.

Для осиновых и пихтовых лесов урочища в травяном ярусе характерно присутствие реликтов широколиственных лесов с третичного периода (Ильин, 1941; Куминова, 1960; Положий, Крапивкина, 1986): папоротника - щитовника мужского (Dryopterix filfix-mas (L.) Scott.), коротконожки лесной (Brachypodium sylvaticum (Huds.) Beauv.) и подмаренника (ясменника) душистого (Galium (Asperula) odoratum (L.) Scop.). При дальнейших исследованиях могут быть найдены и другие реликтовые 
Видовой состав пихтово-осинового коротконожково-разнотравного с яблоней леса

\begin{tabular}{|c|c|c|}
\hline Вид & Обилие & Фенофаза \\
\hline Populus tremula $\mathrm{L}$. & Cop2 & Плодоносит \\
\hline Abies sibirica Ledeb. & Sol-Sp & Плодоносит \\
\hline Malus sieversii (Ledeb.) M. Roem. & $\mathrm{Sp}$ & Плодоносит \\
\hline Crataegus korolkowii L. Henry & Sol & Плодоносит \\
\hline Sorbus tianschanica Rupr. & Sol & Плодоносит \\
\hline Rosa alberti Regel & $\mathrm{Sp}$ & Плодоносит \\
\hline Rubus idaeus L. & Sol & Цветет \\
\hline Ribes meyeri Maxim. & Sol & Цветет \\
\hline Humulus lupulus L. & Sol & Плодоносит \\
\hline Atragene sibirica L. & Sol & Цветет \\
\hline Millium effusum $\mathrm{L}$. & Cop1 & Цветет \\
\hline Brachypodium sylvaticum (Huds.) Beauv. & $\mathrm{Sp}$ & Вегетирует \\
\hline Dactylis glomerata L. & Sol & Цветет \\
\hline Aegopodium alpestre Ledeb. & Sp-Cop1 & Цветет \\
\hline Anthriscus sylvestris (L.) Hoffm. & Sol & Цветет \\
\hline Geranium collinum Steph. & Sol & Цветет \\
\hline Geranium albiflorum Ledeb. & Sol & Цветет \\
\hline Polemonium caucasicum N. Bush. & Sol & Цветет \\
\hline Dryopterix filfix-mas (L.) Schott & Sol & Вегетирует \\
\hline Galium odoratum (L.) Scop. & Sol & Плодоносит \\
\hline Gallium boreale L. & Sol & Цветет \\
\hline Cerastium davuricum Fisch. ex Spreng. & Sol & Цветет \\
\hline Cerastium pauciflorum Stev. ex Serg. & Sol & Цветет \\
\hline Lathyrus gmelinii Fritsch & Sol & Цветет \\
\hline Aquilegia karelinii (Baker) O. et B. Fedtsch. & Sol & Цветет \\
\hline Arctium tomentosum Mill. & Sol & Вегетирует \\
\hline Artemisia vulgaris L. & Sol & Вегетирует \\
\hline Thalictrum minus L. & Sol & Вегетирует \\
\hline Ranunculus grandifolius C. A. Mey. & Sol & Вегетирует \\
\hline Geum urbanum L. & Sol & Вегетирует \\
\hline Stachyopsis marrubioides (Regel) Ik.-Gal. & Sol & Вегетирует \\
\hline Bistorta elliptica (Willd. ex Spreng.) (Kom.) & Sol & Вегетирует \\
\hline Seseli schrenkianum (C. A. Mey.ex Schischk.) M. Pimen. et Sdobnina & Sol & Вегетирует \\
\hline Aconitum leucostomum Worosch. & Sol & Вегетирует \\
\hline Lamium album L. & Sol & Вегетирует \\
\hline
\end{tabular}

растения, такие как Festuca gigantea (L.) Vill., Bromopsis benekenii (Lange) Holub, Cardamine impatiens L., Geranium robertianum L., Stachys sylvatica L. и др. На примере этих двух описаний мы можем судить о наличии на исследуемой территории сибирского ботанико-географического элемента на уровне фитоценозов, а не только отдельных представителей флоры в лице джунгарского варианта черневой тайги.

В окр. кордона Осинники в ущельях Солдатское, Пихтовое и Черная Речка распространены высокотравья, пихтовники и осиновые леса сходного флористического состава. В Северном Тянь-Шане реликты широколиственных лесов представлены в плодовых абрикосово-боярышниково-яблоневых лесах (Данилов, 2002) и сложных (Быков, 1985) или субнеморальных (Ролдугин, 1989) ельниках.

У горных вершин отмечены местонахождения маральего корня - Rhaponticum carthamoides (Willd.) Iljin, занесенного в Красную книгу Казахстана (Байтулин, Синицина, 2014).

Из антропогенных влияний на растительный покров следует указать на искусственные насаждения сосны обыкновенной (Pinus sylvestris) на крутых горных склонах. 
Видовой состав высокотравного лисохвостово-борово-разнотравного луга

\begin{tabular}{|c|c|c|}
\hline Вид & Обилие & Фенофаза \\
\hline Malus sieversii (Ledeb.) M. Roem. & Sol & Плодоносит \\
\hline Alopecurus pratensis $\mathrm{L}$. & Cop1 & Цветет \\
\hline Millium effusum L. & Cop1 & Цветет \\
\hline Dactylis glomerata L. & $\mathrm{Sp}$ & Цветет \\
\hline Poa pratensis L. & Sol & Цветет \\
\hline Anthriscus sylvestris (L.) Hoffm. & $\mathrm{Sp}$ & Цветет \\
\hline Angelica decurrens (Ledeb.) B. Fedtsch. & Sol & Вегетирует \\
\hline Inula helenium L. & Sol & Вегетирует \\
\hline Heracleum dissectum Ledeb. & Sol & Вегетирует \\
\hline Aegopodium alpestre Ledeb. & Sol & Цветет \\
\hline Bupleurum longifolium L. & Sol & Цветет \\
\hline Cerastium davuricum Fisch. ex Spreng & Sol & Цветет \\
\hline Cerastium pauciflorum Stev. ex Ser. & Sol & Цветет \\
\hline Crepis sibirica $\mathrm{L}$. & Sol & Цветет \\
\hline Polemonium caucasicum N. Bush & Sol & Цветет \\
\hline Galium boreale $\mathrm{L}$. & Sol & Цветет \\
\hline Galium aparine $\mathrm{L}$. & Sol & Цветет \\
\hline Pulmonaria dacica (Simonk.) Simonk & Sol-Sp & Плодоносит \\
\hline Lathyrus gmelinii Fritsch & Sol & Цветет \\
\hline Myosotis sylvatica Ehrh. ex Hoffm. & Sol & Плодоносит \\
\hline Cirsium arvense (L.) Scop. & Sol & Вегетирует \\
\hline Serratula coronate L. & Sol & Вегетирует \\
\hline Artemisia vulgaris L. & Sol & Цветет \\
\hline Lamium album $\mathrm{L}$. & Sol & Цветет \\
\hline Ranunculus grandifolius C.A. Mey. & Sol & Цветет \\
\hline Potentilla asiatica (Th. Wolf.) Juz. & Sol & Цветет \\
\hline
\end{tabular}

Острая экологическая проблема заключается в том, что яблоня в лесном поясе массово поражена вредителем - яблоневой молью.

Массив горных лесов между реками Улькен Баскан и Лепсы в ГНПП Жонгар-Алатауский требует особой охраны и дальнейшего исследования. Необходимо изучить типологический состав лесов и провести инвентаризацию флоры всего лесного массива.

Несмотря на давнюю историю изучения, мы до сих пор не располагаем исчерпывающей информацией по растительному покрову Джунгарского Алатау и другим районам Казахстана. Необходимо продолжать детальные исследования на основе наследия прошлого и новейших научных методик и представлений.

\section{ЛИТЕРАТУРА}

Байтулин И. О., Синицина В. Г. Рапонтикум сафлоровидный //Красная книга Казахстана. Т. 2: Растения. Алматы, 2014. - С. 304.

Быков Б. $\boldsymbol{A}$. Еловые леса Тянь-Шаня. - Алма-Ата: Наука, 1985. - 180 с.

$\boldsymbol{B}$ олкова $\boldsymbol{E}$. A. Растительный покров гор. Горные провинции // Ботаническая география Казахстана (в пределах пустынной области). - СПб., 2003. - С. 167-191; 217-222.

Голоскоков В. П. Флора Джунгарского Алатау. - Алма-Ата: Наука, 1984. - 224 с.

Данилов М. П. Неморальный элемент в растительном покрове Заилийского Алатау // История, природа, экономика: Материалы науч.-практ. конф., посвящ. 125-летию Омского регионального отделения РГО. - Омск, 2002. - C. 105-109. 
Ильин М. М. Третичные реликтовые элементы в таежной флоре Сибири // Материалы по истории флоры и растительности СССР. - М.-Л., 1941. - Вып. 1. - С. 26-41.

Коровин Е. П. Растительный покров Средней Азии и Южного Казахстана. Кн. 2. - Ташкент: Изд-во АН УзСCP, 1962. - 546 c.

Куминова А. В. Растительный покров Алтая. - Новосибирск: Изд-во СО АН СССР, 1960. - 450 с.

Положий А. В., Крапивкина Э. Д. Реликты третичных широколиственных лесов во флоре Сибири. - Томск: Изд-во ТГУ, 1986. - 157 с.

Родин Л. И. Ботанико-географический очерк Лепсинского района Джунгарского Алатау // Изв. гос. географ. о-ва, 1933. - Т. 65. - Вып. 4. - С. 296-319.

Ролдугин И. И. Еловые леса Северного Тянь-Шаня. - Алма-Ата: Наука, 1989. - 304 с.

Рубцов Н. И. Растительный покров Джунгарского Алатау. - Алма-Ата: Изд-во АН КазССР, 1948. - 184 с. 